\title{
Kívülállók közössége? A communitas megnyilvánulási formái és funkci- ója egy alternatív középiskolában
}

\author{
Szentesi Balázs \\ balazs.szentesi@gmail.com \\ https://doi.org/10.51624/SzocSzemle.2020.3.2 \\ Beérkezés: 2020.02.04. \\ Átdolgozott változat beérkezése: 2020. 05. 28. \\ Elfogadás: 2020. 07. 14.
}

\begin{abstract}
Összefoglaló: A tanulmány egy budapesti alternatív gimnázium (a „Diákház”) belső diskurzusát vizsgáló, etnográfiai módszerekkel végzett kutatás eredményeire épül. A Diákházban a tanárok iskolaelhagyó, a felnőttekkel, tanárokkal, iskolákkal szemben többnyire elutasító, szociokulturálisan sokszínú diáksággal dolgoznak. A hagyományostól eltérő pedagógiai eszközök használata mellett ezt a munkát segítik a diákházi diskurzusban megjelenő szubkulturális koncepciók: a másság, a deviancia, a kulturális mainstreammel szembeni ellenállás, a marginalitás és a communitas, a státuszkülönbségek nélküli közösség élménye. Az írás néhány példán keresztül bemutatja, ahogyan az oktatási intézményi keretben fenntartott communitas megjelenik és megerősítődik a diákházi kommunikációs színtéren, és ahogyan a struktúrán kívüliség élménye hozzájárul a diákok strukturális pozícióemelkedéséhez.
\end{abstract}

Kulcsszavak: communitas, szubkultúra, alternatív oktatás, iskolai kimaradás

Írásom egy iskolaelhagyó diákokkal foglalkozó budapesti alternatív gimnáziumban, a „Diákházban” ${ }^{1}$ végzett résztvevő megfigyeléses kutatás eredményeire épül. A kutatás célja az iskolai színtéren zajló kommunikációban létrejövő problémamegoldó tudás leírása volt. A munka egyes eredményei olvashatók máshol megjelent tanulmányaimban (Szentesi 2013a, 2019a, 2019b, 2020). Jelen tanulmány a kutatás eredményeinek egy részletére, a communitas diákházi megjelenésére fókuszál.

\section{A Diákház}

A Diákház egy Budapesten közel 30 éve múködő, alapítványi fenntartású, tandíjmentes gimnázium, egy ún. „második esély” iskola, ahova más középiskolákból kimaradó diákokat vesznek föl. A diákság demográfiai adatait kérdőívvel próbáltam

1 Az intézmény és az adatközlők nevét megváltoztattam a szövegben. (Bár az iskola tanárai utólag kifejezetten kérték az intézmény nevesítését, az anonimitás megőrzésére vonatkozó kutatói etikai elvárást fontosabbnak ítéltem). 
felvenni, a diákok formalizáló hatalmi eljárásokkal szembeni ellenállása miatt azonban (ld. később) - egy másik jelen lévő kutatóhoz hasonlóan - sikertelenül. Így a diákok életkorát, nemi, nemzetiségi arányát, lakhely szerinti megoszlását több év tapasztalata, néhány év felvételi adatai és az adatközlőktől nyert információk alapján némi szórással tudom megbecsülni. A kutatás több fázisban zajlott (ld. később), itt a második fázis adataiból indulok ki. A 2011-2012-es tanévben 107 diák iratkozott be a Diákházba. Nagy többségük a 16-25 éves korosztályba tartozott, illetve volt néhány (nagyjából 8\%) 26-32 éves diák, átlagéletkoruk 20 év volt. A lányok és a fiúk aránya 54/46\% volt. Volt pár (3-4\%) cigány és körülbelül ugyanennyi egyéb nemzeti/etnikai identitású (pl. török, perzsa, guineai) diák. A budapestiek aránya a diákság 2/3-át, 3/4-ét tette ki, a többiek többnyire a budapesti agglomerációban laktak, néhány fő pedig távolabbi városokban, falun, tanyán. (Ezek az arányok nagyságrendileg más évekre is érvényesek).

Az egyes diákok iskolai kimaradásának hátterében igen különböző tényezők állhatnak, de mindegyiküknél megjelenik a serdülőkori krízis tünetei és kockázati tényezői (ld. Gyenge 2014; Holmes - Rahe 1967) közül egy vagy több. Pl. szociális gátlás, marginalizálódás, szerepléstől, iskolai megnyilvánulásoktól való félelem, önértékelési problémák, ritkábban alkohol- és drogfogyasztás, önsértő magatartás, illetve a szülők válása, halálozások a családban, bántalmazó vagy elhanyagoló szülők, állami gondozás stb. Ezek tekintetében a diákság nagy diverzitást mutat, ugyanakkor a legtöbbjükre jellemzők az autoritáskrízis megnyilvánulásai - pl. a felnőttséggel azonosított értékek megkérdőjelezése, provokatív megnyilvánulások, szembehelyezkedés a tekintélyszemélyekkel, a felnőttekkel, iskolával, tanárokkal szembeni gyanakvás, ellenállás (Hajduska 2015). A diákok alkotta csoport szociokulturálisan igen sokszínú képet mutat, illetve jellemző egyes periférikus társadalmi kategóriák, devianciák és a depriváció jelenléte. Alacsony és magas iskolai végzettségű, illetve jómódú és szegény szülők gyermekei, itthoni és határon túli magyarok, bevándorlók és bevándorlók Magyarországon született gyermekei, különböző ifjúsági szubkultúrák (pl. punk, rapper, hippi, gót, skinhead) tagjai, LMBTQ személyek, fogyatékkal (pl. mozgássérülés, hallássérülés, beszédhiba, Asperger-szindróma) vagy részképességzavarral (pl. diszlexia, diszkalkulia, figyelemhiányos zavar) élők egyaránt találhatók közöttük.

A Diákházat irányító tízfős munkaközösségnek (a „stábnak”) azok a tanárok a tagjai, akik (az óraadó tanároktól eltérően) napi szinten sok időt töltenek a diákokkal, és mentori feladatokat is ellátnak. A diákok egy részéhez hasonlóan többségüknek van valamilyen fiatalabb vagy jelenkori szubkulturális kötődése (pl. hazai underground). Ugyancsak a diákokhoz hasonlóan a hagyományosabb iskolákról általában negatív képük van.

A szociokulturálisan sokszínű és több esetben lázadó, nehezen kezelhető diáksággal végzett munkához az alapító tanárok sajátos pedagógiai rendszert alakítottak ki. Megszüntették a legtöbb hagyományos iskolai formalitást, szabályt, fegyelmező 
és pedagógiai eszközt (pl. a magázódást, a bejárási kötelezettséget, a napi számonkérést, az intőt, a korcsoport szerinti osztályokat stb.), amelyek helyett alternatív formális és nem formális fegyelmező technikákkal (pl. szerződéskötéssel, a figyelem megvonásával/megadásával, egyezkedésekkel), személyre szabott bánásmóddal és tanulási tervvel, a diákok mentori támogatásával, valamint az iskolai döntéshozatalba való (bizonyos szintű) bevonásával dolgoznak. Mindemellett az iskolai múködésbe beleszövődik egyfajta szubkulturális múködésmód is, amely bizonyos szubkulturális gyakorlatokat és koncepciókat (pl. szubkulturális stílus, sokszínűség, marginalitás, ellenállás, communitas) tesz elérhetővé a Diákház tagjai számára. (Erről részletesebben írok egy korábbi tanulmányomban: Szentesi 2019b).

\section{Módszertan}

A Diákházban 2004 és 2016 között² időben hosszan elnyúló terepmunkát végeztem etnográfiai módszerekkel, főleg résztvevő megfigyeléssel. ${ }^{3}$ A kutatás két fő fázisában (2004. február-július és 2011. október - 2012. június) ${ }^{4}$ megfigyeléseket végeztem a tanórákon, a szünetekben, a tanári megbeszéléseken, a felvételi beszélgetéseken, az iskolai fórumokon, az alkalmi eseményeken és a tanítási időn kívüli aktivitásokban (pl. zenekari vagy táncpróbák, sörözések, házibulik, kirándulások). A főbb fázisok között és a második fázis után a változások követése, a feldolgozás során felmerülő kérdések tisztázása, az újabb adatok gyưjtése érdekében tartottam a kapcsolatot kulcsadatközlőimmel, és évente néhány alkalommal látogatásokat tettem a Diákházban.

A résztvevő megfigyelés segítségével a diákházi diskurzus sűrủ leírását (thick description), azaz „a megformált viselkedések illékony példáival íródott” (Geertz 2001: 202) kulturális szöveg értelmezését igyekeztem létrehozni. Azt akartam feltárni, hogy a megfigyelt kommunikációs gyakorlatok alkalmazói hogyan jelenítik meg önés egyéb értelmezéseiket, hogyan vesznek részt a diskurzust meghatározó értelme-

2 A 12 éves időszak alatt történt változások a Diákház múködésében többnyire apró módszertani/eljárásbeli változtatások, amelyek az iskola pedagógiai alapvetéseit, illetve a szubkulturális müködés és communitas általam leírt jelenségeit nem érintik.

3 Kutatásom Mészáros (2014) 2006-ban végzett kutatása mellett az első hazai, résztvevő megfigyeléssel végzett iskolakutatások közé tartozik. Kapcsolható a nemzetközi pedagógiai etnográfia, azon belül is a szúkebb területet lefedő pedagógiai antropológia kutatásokhoz. Az iskola mint kutatási terep és a résztvevő megfigyelés mellett az ide tartozó munkák sajátommal közös elemei a nyitott végú kérdéseket tartalmazó interjúk alkalmazása a jelenségek belső olvasatának megértéséhez, a kultúra koncepciójának használata, és az, hogy ezeket a kutatásokat inkább „otthon” végezték, mint külföldön (Anderson-Levitt 2012). Ezek a munkák jellemzően az iskolai kultúra és az etnikai/nyelvi kisebbségek kultúrája közötti eltérésekből adódó, illetve a társadalmi osztályokhoz és nemhez kapcsolódó iskolai sikertelenségre fókuszálnak (Anderson-Levitt 2012; Delamont 2012). Hazai viszonylatban - bár nem hosszan tartó résztvevő megfigyelésre épülnek - Erőss (2012) ide sorolja a hasonló témájú, (főleg cigány) kisebbségek és bevándorlók iskolai helyzetét vizsgáló munkákat (pl. Csongor 1991; Feischmidt-Nyíri 2006; Neumann-Zolnay 2008). Iskolán kívüli terepe ellenére utóbbiak közé tartozónak tartom saját korábbi kutatásom (Szentesi 2013b) is. A jelen tanulmány alapját képező munkám ugyanakkor el is tér témájában az előzőktől. Bár a kulturális különbségek és az iskolai sikertelenség kapcsolata megjelenik benne, inkább az iskolai kultúrával osztályi (pl. Willis 2000) vagy szubkulturális (pl. Mészáros 2014) alapon szembehelyezkedő fiatalokról szóló munkákhoz hasonlít. Viszont utóbbiaktól is különbözik abban, hogy itt a feszültség nem a vizsgált iskola és a tanulók kultúrája/kultúrái között jelentkezik, hanem a vizsgált iskola a tanulókkal együtt helyezkedik szembe más iskolákkal (vagy egy „többségi" kultúrával, amelyet szemükben ezek az iskolák képviselnek), valamint abban, hogy nem a tanulók vagy a pedagógia sikertelenségéről, hanem éppen fordítva, a sikertelenség leküzdéséről szól.

4 A tanulmányban szereplő példák a második fázisból származnak, de a segítségükkel bemutatott jelenségek a kutatás ideje alatt általánosan érvényesek voltak a Diákházra, és információim alapján azóta is érvényesek maradtak. 
zések feletti alkudozásokban, ezeket hogyan használják az egymáshoz való viszonyaik alakításában és bizonyos problémáik megoldásában.

A résztvevő megfigyelés kiegészítéseként 10 diákkal, 8 tanárral és egy segítő szakemberrel készítettem félig strukturált interjút. Készítettem továbbá fotókat, video- és hangfelvételeket, valamint gyưjtöttem az adatközlők által a közösségben vagy a közösség számára készített képi, video-, illetve online anyagokat is.

\section{Sajátkultúra-kutatás}

A terepen betöltött pozícióm nagymértékben hasonlított arra, amelyet Bennett (2003) és Hodkinson (2005) belső (insider) kutatói pozíciónak neveznek. ${ }^{5}$ Mindketten a zene- és stílusorientált ifúsági kulturális csoportok kutatása kapcsán használják a fogalmat azokra a kutatókra, akik korábban maguk is tagjai voltak a vizsgált csoportnak. ${ }^{6}$ Bennett (2003) az ifjúsági kultúrák jelenkori kutatására nagyon jellemzőnek tartja ezt a megközelítést. Saját munkámat is ezek közé a kutatások közé sorolom. Részben azért, mert a 90-es évek elején magam is diákja voltam a vizsgált intézménynek, másrészt tinédzserkoromtól kezdve résztvevője voltam különböző ifjúsági/zenei szubkulturális színtereknek, így a mostani diákok (többségének) szubkulturalista élménye és az iskola múködése - a maga sajátos szubkulturális vonásaival - több oldalról is ismerősek voltak számomra.

A belső pozíció előnyei közé tartozik, hogy megkönnyíti a belépést a terepre, mivel a megfigyelő már eleve illeszkedik a környezetbe (Anderson 2006; Riemer 1977), megkönnyíti a terepen a bizalmi viszonyok kialakítását, a pontosabb interpretáció kialakítását, a téves információk kiszűrését (Hodkinson 2005; Riemer 1977), és olyan betekintést enged a résztvevők érzelmi élményeibe, személyes látásmódjába, amelyet más módszertan nem tesz lehetővé (Tetnowski-Damico 2014). Terepre lépésemkor mind a tanárok, mind a diákok számára nyílttá tettem, hogy egykori diákházas vagyok, aki most kutatóként van jelen. A diákházas múltam és a szubkulturális tőkém ${ }^{7}$ alkalmazása valóban biztosította számomra a belső pozícióval járó fentebb sorolt előnyöket. Ugyanakkor a közösség életébe való elkerülhetetlen bevonódás az

5 A saját közösség kutatására más elnevezések is születtek. Yang (1972) első kézből származó terepmunkának (first-hand fieldwork) nevezte, amikor saját szülőfalujában vizsgálta önmaga és társas környezete életét. Riemer (1977) az „ismerősség” lehetőségeit kiaknázó (opportunistic) kutatásnak nevezi, amikor a kutató a saját élettörténetéből, élettapasztalataiból, az ismerős helyzetekből származó „kéznél lévő" tudás nyújtotta lehetőségeket használja a kutatás során. Hayano (1979) önetnográfiának (auto-ethnography) hívja, amikor a kutató maga is tagja vagy részese a vizsgálat tárgyát képező közösségnek, illetve aktivitásnak. Brewer (2005) megfigyelő részvételnek (observant participation) nevezi a kutató már létező szerepének hasznosítását egy számára ismerős környezet kutatásában, és megkülönbözteti az ismeretlen környezetben végzett, új szerep felvételével járó résztvevő megfigyeléstől.

6 A valamikori szubkulturalistákból lett kutatók által végzett, a szubkulturalisták belső nézőpontját is megjelenítő (poszt)szubkultúra-kutatások az 1980-as évektől sokasodtak meg a birminghami iskolához (Centre for Contemporary Cultural Studies) köthető szubkultúra-kutatók többségét jellemző „külső” értelmezésekre adott válaszokként. Más területeken (főleg az etnikai kisebbségek és a nemi szerepek kutatásánál) már a 70-es évekre általános nézőponttá vált, hogy a kutatás alanyaival azonos csoportba tartozó kutatók sok szempontból előnyt élveznek a kívülálló kutatókkal szemben (Zinn 1979).

7 Thornton (1995) fogalma Bourdieu (1999) kulturális tőke fogalma alapján. A tudás, a viselkedés és a felhalmozott javak szubkulturálisan felismert formáit jelöli, amelyek alapján a szubkulturalisták létrehozzák a fősodor/szubkultúra, a kommerciális/ alternatív dichotómiákat, és az „átlagemberekkel” szemben felértékelik magukat. Az én esetemben ez leginkább a diákok által kedvelt különböző szubkulturális zenei előadók ismeretét, illetve a külső szubkulturális stíluselemek felismerését jelentette. 
érzelmi viszonyokba, pozícióharcokba és konfliktusokba való bevonódással is járt, amely a saját tevékenységeimre, motivációimra, a kutatóságom és a csoporttagságom összeegyeztetésének nehézségeire való tudatosabb reflexiót is megkövetelte. ${ }^{8}$ De éppen ez a bevonódás, illetve ennek megfigyelése tette lehetővé, hogy jobban értsem a Diákház belső viszonyait, a diákházasok érzelmi állapotait és motivációit, amelyek közül néhányat a jelen írásban közölt példákban is megjelenítek.

A kutató intenzívebb bevonódásakor (amelyre a saját kultúra kutatásakor nagyobb az esély) fel szokott merülni az elfogultság, illetve az eredmények érvényességének kérdése is. Az általam alkalmazott interpretív megközelítésben (Geertz 2001) a kultúra értelmezések (a világról alkotott interpretációk) hálója, az antropológus/ etnográfus kutató pedig a közösség tagjai által osztott interpretációk (másod-harmadkézből való) interpretációit írja le. Ugyanakkor e megközelítés posztmodern kritikusai (pl. Clifford-Marcus 1986; Marcus-Fischer 1999) megjegyzik, hogy még mindig a modernista külső/belső ellentétre épít, amikor a megfigyelő külső pozíciójából indul ki, mintha a társadalmi valóság konstrukciójának gyakorlatait megfigyelő kutatók nem ugyanennek a gyakorlatnak a részesei volnának. Az (etnográfiai) írás nem egy mások tapasztalatait bemutató eszköz, hanem inkább a „másik” megkonstruálásának, újraformálásának ${ }^{9}$ médiuma és gyakorlata. Olyan társadalmi cselekvés, amely mindig valamilyen politikai-gazdasági környezetbe ágyazva fejti ki hatását, és sohasem független a szerző által alkalmazott kategorizációktól, illetve a szerző (politikai) szándékaitól. ${ }^{10}$

Bennett (2003) a szubkultúrák jelenkori (insider) etnográfiai kutatását a közös zenei érdeklődésre épülő szabadidős tevékenységekkel és stílusválasztásokkal jellemezhető kutatók és adatközlők együttes produktumának tekinti. Hodkinson (2005) szerint az ilyen kutatások érvényessége nem a kutatónak a kutatott csoport belső látásmódjához való kiemelt hozzáféréséből fakad (mivel az adatközlők értelmezései sokfélék, és nem alkotnak valamilyen monolitikus belső „igazságot”), hanem a kutató és az adatközlők interpretációinak együttességére, illetve a kutatásban érintett személyek visszaigazolásaira ${ }^{11}$ alapozható.

Az insider kutatás lényege tehát a résztvevőkkel közös tudás alakításában, a társadalmi valóság megkonstruálásában való együttes részvétel (és a kutató erre irányuló tudatos figyelme), amely ennek a valóságnak az interpretációját hitelessé teszi.

8 Az ilyen esetekre vonatkozó (ön)megfigyeléseket és elemzésüket részletesen tárgyalom másutt (Szentesi 2018).

9 Az itt tárgyalt belső kutatói pozíció esetében azt is mondhatnánk, hogy a „saját" megkonstruálásáról van szó.

10 Magam szimpatizálok a diákházi modellel, és nem titkolt szándékom a teljes munkámmal a hagyományos oktatás egyfajta alternatíváját/kiegészítőjét felmutatni. Jelen tanulmány ennek a munkának egy kis részlete.

11 Az én esetemben több tanár és egy diák is olvasta a teljes munkát, akik egyöntetúen érvényesnek érezték a szövegben leírtakat. (Egyelöre nem tudtam a többi érintettel felvenni a kapcsolatot). 


\section{Elmélet: communitas és szubkultúra}

Munkám során több diszciplináris és kutatási területet érintettem, ${ }^{12}$ de jelen írás fókuszához kapcsolódva ezek közül csak Turner ${ }^{13}$ antropológiai munkásságából és a szubkultúra-kutatás területéről emelem be a communitas és a szubkultúra fogalmait. Röviden definiálom őket, és bemutatom kapcsolatukat.

Van Gennep (2007) az átmeneti rítusok - a hierarchikus rendbe tagozódó társadalmi státuszok közötti átlépéseket kísérő szimbolikus gyakorlatok - három fázisát írja le: az elválasztó fázist (amely az egyént vagy csoportot elválasztja korábbi társadalmi helyzetétől), a határhelyzeti vagy liminális fázist (amelyben az egyénre vagy csoportra a korábbi helyzetéhez kapcsolódó társadalmi elvárások már nem, az újak pedig még nem érvényesek) és a befogadó fázist (amelyben a rítus alanyait a közösség újra befogadja, de már egy újabb társadalmi helyzetben). Turner (2002) a rituális folyamatot elemző munkájában mutatja be a középső, liminális fázisban megjelenő communitas állapotát, amely a benne részesülők alázatosságával, bajtársi és egalitárius érzéseivel, a közöttük fennálló rang- és státuszbeli különbségek eltűnésével vagy homogenizálódásával jellemezhető. A communitas az egyének közötti egyenrangúság, a strukturálatlan vagy kezdetlegesen strukturált és viszonylag differenciálatlan közösség, együttesség élménye, amely a hierarchikus rendszerbe rendeződő, strukturált társadalmi lét ellentéte - Turner fogalmával: antistruktúra. A törzsi rítusokon túltekintve a communitasra való törekvést általános emberi igénynek tekinti, a communitas és struktúra ciklikus váltakozását pedig minden társadalom történelmében megjelenő folyamatnak. A communitas fenntartására irányuló igyekezetek elkerülhetetlenül strukturális szerveződéshez, vagyis az előbbi hanyatlásához vezetnek, amelyet később a communitas újfajta formájának megjelenése követ. A communitas általában ott jelenhet meg, ahonnan a struktúra visszavonul, így pl. a struktúra határain (a marginalitásban) és a struktúra „alatt” (az alsóbbrendú-

12 Felhasználtam a serdülököri krízis (Erikson 1950) és a krízishez kapcsolódó rizikófaktorok (Holmes-Rahe 1967) elméleteit a diákházi diákok jellemzésére és problémáik bemutatására. Továbbá, mivel a diákok korábbi iskoláikban megjelenő kommunikációs zavaraiból indultam ki, felhasználtam a kommunikáció matematikai (Shannon-Weaver 1986) és interakcionista (Watzlawick et al. 2009) modelljét a kommunikáció értelmezési zavarainak definiálására. Ezenkívül Linehan (2010) érvénytelenítő környezetről alkotott pszichológiai elméletét és a kommunikáció participációs elméletének (Horányi 2007) fogalmait használtam a diákok Diákházban megfogalmazódó közös problémájának, az érvénytelenségélménynek a definiálására. (Az érvénytelenség fogalma itt az ágens felkészültségeinek/tudásainak alkalmazhatatlanságára, az ágens által felvetett problémák és értelmezések legitimitásának hiányára utal egy adott intézményi - itt iskolai - színtéren - Id. Szentesi 2019a). Az iskolát interkulturális kommunikációs színtérként kezeltem, amelyhez a kultúra és az interkulturális kommunikáció interpretív (Geertz 2001) és kritikai (Hall 1996) megközelítését alkalmaztam. A szubkultúra-kutatás főbb külföldi és hazai irányzataihoz kötődő elméleteket (többek között: Cohen 1955; Hall-Jefferson 1976; Haenfler 2013; Hebdige 1979; Rácz 1998; Thornton 1995) a diákházi szubkulturális gyakorlatok és koncepciók azonosítására alkalmaztam. Továbbá felhasználtam Turner (2002) communitas-elméletét a diákházi müködés elemzéséhez.

13 Victor W. Turner (1920-1983) a brit szimbolikus antropológia központi alakja. Az 1950-es évek első felében folytatott megfigyeléseket az afrikai ndembuk között. Első föbb munkájában (Turner 1957) megjelenő antropológiai újítása a társadalmi dráma fogalma, amellyel a ndembu társadalmi struktúra és szabályszerúségek mögött rejlő ellentmondások és konfliktusok kezelésének visszatérő lépéseit írta le. Ebben a folyamatban a rítusok is szerepet kapnak, amelyeket Turner eleinte strukturalista-funkcionalista megközelítésben csupán egy adott csoport vezetői által használt, társadalmi feszültségeket kompenzáló, konfliktusrendező mechanizmusoknak tekintett. További antropológiai hozzájárulása (Turner 1967) a törzsi rítusok, illetve a rituális szimbólumok részletes leírása, definiálása, funkcióik és jellemzőik elkülönítése, módszeres elemzése. Ekkor már a strukturalista-funkcionalista szemlélettől távolodva a (rituális) szimbólumokat a társadalmi rend megjelenítésére, reprodukálására, illetve a társadalmi ellentmondások elfedésére használt elsődleges eszközöknek tekintette, amelyek manipulálásával a társadalmi szerveződés alapelveit konkrét személyek szabályozni képesek. 1969-ben megjelent meghatározó munkájában (Turner 2002) foglalta össze az átmeneti rítusokról és a rítusok középső fázisát jellemző communitasról (a státuszkülönbségek nélküli közösség állapota) alkotott koncepcióit, amelyeket a ndembu rítusoktól elszakadva már a komplex társadalmakra is kiterjesztett. 
ségben). A komplex iparosodott társadalmakban a communitas - Turner fogalmával - liminoid jelenségekben érhető tetten. Olyan, a meghatározó gazdasági, politikai, strukturális folyamatokon kívül álló egyéni vagy csoporttörekvésekben, amelyek megnyilvánulásai megkérdőjelezik a szélesebb társadalmi struktúrát, társadalmi kritikával élnek, vagy javaslatokat tesznek a társadalmi rend forradalmi átrendezésére. Turner egyebek között ilyennek tekinti a státuszokhoz kötött társadalmi rendből „kiiratkozó” beatnik és hippi szubkultúrákat.

Turner nyomán többen más szubkultúrákkal kapcsolatban is leírják a communitasélményt. Pl. punk színtereknél (Ensminger 2013; Rohrer 2014), ravereknél (Hutson 2000; Rill 2006), a hip-hop (Viega 2013) vagy általában véve az ifúsági zenei szubkultúrák kapcsán, mint Sylvan (2002), aki a kulturális fősodor (struktúra) szubkulturális kritikáját, illetve az azzal való szembefordulást hangsúlyozó ifjúsági szubkultúrák központi elemének tekinti a világlátásukat is tükröző zenét és a zene (pl. acid rock, heavy metal, punk, house, alternatív, rap) közösségi fogyasztása során létrejövő spirituális communitas-élményt, de leírják pl. homoszexuális szubkultúráknál is (Haslop et al. 1998). Gelder (2005) a communitast egyenesen a szubkultúra-fogalom variánsai közé sorolja.

A szubkultúra fogalma itt nem részkultúra értelemben jelenik meg, hanem a kulturális ellenállás bizonyos formáit középpontba helyező (gyakran zenei/ifúsági) közösségekre vonatkozik. Haenfler (2013) a szubkultúrát olyan, viszonylag szervezetlen szociális hálózatként definiálja, amely tagjainak közösen osztott identitásával, megkülönböztető jelentésekkel felruházott elképzelések, gyakorlatok és tárgyak alkalmazásával, valamint a konvencionális(nak tekintett) társadalommal szembeni ellenállással vagy az ahhoz viszonyított marginalitás érzésével jellemezhető. ${ }^{14} \mathrm{~A}$ szubkultúrák nem normativak abban az értelemben, hogy az önmaguk definiálására alkalmazott jelentések (amelyek megjelennek pl. a ruházat, a kiegészítők vagy a zene stílusában is) bizonyos mértékig különböznek a szélesebb körben elfogadott normáktól, azaz deviálnak a normától (Haenfler 2013), illetve éppen ez a különbözőség az a jelentés, amelyet hordoznak (Rácz 1998). Az ilyen (leszűkítő) értelemben vett szubkultúrákban tehát nem csak egyfajta közösségi élményként jelenik meg a communitas, hanem a szubkultúra lényegi elemeként, ugyanis az uralkodó renden való kívülállásnak (marginalitásnak/ellenállásnak), a struktúra felfüggesztésének élményét nyújtja.

\section{Communitas és struktúra a Diákházban}

Amikor communitasról beszélek a Diákház kapcsán, egyrészt a személyre szabott pedagógiájukat megalapozó koncepcióra gondolok, amely szerint minden egyén

14 Haenfler (2013) a definícióból kizárja azokat a közösségeket, amelyek önértelmezésének - bár megkülönböztethető szokásokkal, viselettel, érdeklődéssel vagy értékrenddel jellemezhetők (pl. rendvédelmi szervek, élsportolók, egyetemisták) - nem része a fennálló társadalmi-kulturális renddel szembeni ellenállás és/vagy a marginalitás. 
története, képességei és megoldandó problémái egyediek, illetve amely az egyénnek a másoktól való különbözőségét (másságát) önmagában pozitív értékként kezeli. Eszerint a koncepció szerint nincs értelme erősen formalizált rendszerben kezelni a diákokat, a teljesítményüket egymáshoz viszonyítani és hierarchikus rendbe állítani. Ez nem jelenti azt, hogy a Diákházban ne létezne hierarchia, ne volna osztályzás, vagy hogy a tanárok időnként ne próbálnák a diákokat sikeresebb társaik példáján keresztül motiválni, de a sokszínúség, a különbözőség (és az ebben való egyenlőség) felértékelésének ideája olyan erős az iskolában, hogy sikeresen fedi el a létező hierarchiát. ${ }^{15}$

Másrészt a saját communitas-élményükre olykor nyíltan is utalnak a diákházasok, amikor például megfogalmazzák, hogy nem tartják sokra a magasabb státuszt, és nem gondolják, hogy egy magasabb státuszú ember (pl. a diákok szemében egy tanár) többet ér náluk, vagy azt, hogy a Diákházban nem a hagyományos, hierarchikus iskolai viszonyok érvényesek - a tanáriban éppen pelenkás unokáját terelgető Judit néni [iskolai „mindenes”] szavaival: „ez nem egy iskola, ez egy család” ${ }^{16}$

Harmadrészt - mint általában másutt is - a communitas metakommunikatív, illetve szimbolikus módon jelenik meg az iskola mindennapi életében. A Diákházba lépve szembetűnő a kommunikációt uraló (külsősök számára olykor túlságosan is) közvetlen hangvétel és az iskolai státuszok felismerését segítő viszonyítási pontok hiánya. A tanárok és a diákok közötti tegeződés általános, a térkezelés, a mimika bensőséges viszonyokra utalnak, a tanárok külső megjelenése nem hordoz olyan stílusjegyeket, amelyek alapján könnyen megkülönböztethetők volnának a diákoktól. Az életkor látható jelei adhatnak támpontot, de a fiatalabb tanárokat a kívülről érkező látogatók gyakran összetévesztik a diákokkal, sőt az iskolai közösség egy-egy új tagjáról időnként a diákok sem tudják, hogy tanár-e vagy diák az illető. A terek - beleértve a tanári - közösségi használata és az iskola street art elemekkel tarkított belső dekorációjából áradó klubhangulat azt az érzetet kelti, mintha a Diákház kívül állna a hierarchizált társadalmi struktúrán. Itt van olyan tanár, aki maga is rendszeresen beül a diákok közé angolórára, hogy tanuljon. Itt a tanárok és a diákok időnként bevásárolnak egymásnak a szomszéd közértben, vagy együtt cigarettáznak az utcán. A tanári közepén álló ovális tárgyalóasztalhoz tartozó székeken a diákok kabátjai, táskái, illetve ők maguk foglalják a helyet, a tanárokkal közösen étkeznek, kávéznak/teáznak (meg is osztják egymással az ételüket), dolgoznak, játszanak, társalognak vagy éppen zenélnek.

A communitas-élmény fenntartásának pedagógiai funkciója van az intézményi formalitásokat elutasító, a tanárokkal/felnőttekkel szemben gyanakvó diákok bizalmának elnyerésében:

15 Erről bővebben írok másutt (Szentesi 2019b).

16 Természetesen egy család tagjai között is kialakulnak hierarchikus viszonyok. Az idézett kijelentést nem ennek tagadásaként értelmezem, hanem a hagyományos iskolai struktúra és az elöbbit elkerülő diákházi müködés szembeállításaként. 
Anna [tanár]: „Nekünk nagyon fontos minden olyan helyzet, amiben személyesen lehetünk együtt a diákokkal, úgy értem, szerepmentesen, mert ezek a helyzetek teremtik meg azt a bizalmi légkört, amiben a diákok aztán otthon merik, tudják érezni magukat, vagy legalábbis ellazulnak. [...] Ehhez kellenek az ilyen ebédelös, kávézós, cigizős helyzetek [...], mert közel hoznak csak úgy, lélektöl lélekig."

Ugyanakkor - ahogyan korábban már utaltam rá - a struktúra is megjelenik a diákházi mindennapokban. Ritkábban direkt módon, a tanárok és diákok közötti hierarchiára utaló formákban, mint például a diákok kiutasítása a tanáriból a stábülések idejére, de sokkal jellemzőbb, hogy implicit módon a státuszkülönbségeket megkérdőjelező, kifigurázó vagy ellensúlyozni igyekvő megnyilvánulások formájában. Ilyen például egy magasabb státuszú tanár kifüggesztett fotója, amelyet (mintha egy voodoo szertartás kelléke lett volna) átlyuggattak, és a „halált okozhat” feliratot tûzték rá, vagy olyan esetek, amikor a diákok azokat a jellemzőiket (pl. testi erő) hangsúlyozzák valamelyik tanárral szemben, amelyek alapján egy másik színtéren ők kerülhetnének magasabb státuszba.

A struktúra legkifejezettebb módon a vizsgaidőszakokban ${ }^{17}$ jelenik meg, amikor a communitas részlegesen felfüggesztődik, és hagyományos iskolai formalitásoknak, értékelő és fegyelmező eljárásoknak adja át a helyét (osztályzás, az időkeretek szigorúbb kezelése, frontális ülésrend, utasítások a tanároktól a diákok felé, szankciók - pl. szétültetés, kiküldés teremből, formális/alkalmi öltözetek stb.). Ez egyfajta szükséges rossz a diákházasok szemében, amely a tanárok szerint segít a diákoknak felkészülni az érettségi vizsgán várható viszonyokra, utóbbiak viszont általában nem szeretik, és néha zokon is veszik ezeket a hagyományosabb formális kereteket. A vizsgaidőszakok elmúltával aztán újra a communitasra jellemző kommunikáció válik meghatározóvá. A diákházasok ugyanakkor gyakran helyezik a struktúrát a Diákházon kívülre olyan beszélgetéseikben, vagy akár tanórai példákban, amelyek a felnőttek vagy egy bármilyen intézményi környezet (pl. más iskolák, közhivatalok) formalizált, egyúttal bosszantó, álságos, visszaélésekkel teli világáról szólnak.

\section{Diákházi nyilvánosság}

$\mathrm{Az}$ alábbiakban néhány példán mutatom be, ahogyan a communitas élménye (a deviancia, a marginalitás és a kulturális mainstreammel szembeni ellenállás koncepcióival összekapcsolódva) megjelenik és megerősítődik a diákházi kommunikációs színtér résztvevői között. A diákházi nyilvánosság jellegzetes gyakorlatai ezeket az értelmezéseket sûrített formában teszik hozzáférhetővé a diskurzus résztvevői számára. ${ }^{18}$

\footnotetext{
17 A kutatás második fázisa idején negyed-, de korábban fél-, később pedig harmadévenként tartottak vizsgaidőszakokat.

18 A bemutatottakon kívül ide tartozik még a tér street art és (föleg punk) szubkulturális elemeket is magába foglaló dekorációja, az iskolai ünnepnek a középkori karneválok státuszmegfordításaihoz hasonló dramatikus játékai, illetve az online közösségi felületeken megjelenített tartalmak. Mindegyikben megjelennek egyebek mellett a communitas, illetve a communitas és struktúra szembeállításának példái, ugyanakkor taglalásuk itt terjedelmi okokból nem lehetséges.
} 


\section{Stílus}

A külsőhöz, az öltözködéshez kapcsolódó gyakorlatok és tárgyak, ahogyan a szubkulturalistáknál is, alkalmasak a különbözőség, az egyediség, az ellenállás megjelenítésére (Haenfler 2013; Rácz 1998). Azok a diákok, akik kötődnek valamilyen szubkultúrához, a szubkulturális színtereiken szokásos módokon hangsúlyozzák a társadalom fóáramától való távolságtartásukat. Ilyen például a hajviselet. A Diákházban lehet találkozni mohawk ${ }^{19}$, rasztás vagy szokatlan/látványos módokon nyírt/festett hajat viselő fiatalokkal. A különbözőség megjelenítésére alkalmasak továbbá a testfelületet borító tetoválások és az ábrákat látni engedő ruházat vagy a szájpiercingek, fültágítók és más testékszerek is. Ugyanígy a különböző feliratokkal kidekorált dzsekik, a punk, hippi, house-os/diszkós, raszta, skinhead, hip-hop és egyéb szubkulturális stílusokat megjelenítő ruházat vagy a hagyományos nemi szerepeknek nem megfelelő öltözködés és attitűdök is alkalmasak erre a célra. Utóbbi főleg a butch lányoknál ${ }^{20}$ jelenik meg a fiús ruházat és hajviselet, illetve a harcos kiállás különböző formáiban.

Egyesek a stílusukkal alkalmanként extrém módon kiemelik devianciájukat. ${ }^{21} \mathrm{Pl}$. Panni [diák] egyik nap 20 cm-es mohawkkal jelent meg az iskolában, amellyel láthatólag még diáktársait és a tanárokat is meglepte (megjelenése extremitását ráadásul kiegészítette a kabátja alatt magával hozott házi patkányával, valamint egy történettel a szürkemarhájukról, amelyet a tanyájukon tartanak, ahonnan időnként stoppal jár be).

A stílus ilyen alkalmazása nem minden diákra jellemző (nagyjából a diákok felére, kétharmadára), a tanárok közül pedig csak Istvánra, az igazgatóra ${ }^{22}$, akinek az évtizedek óta növesztett, gumikkal összefogott szakálla - bármilyen öltözettel párosulva - extrém megjelenést kölcsönöz. Egyszer élvezettel mesélte a diákoknak, hogy külföldön járva betévedt egy raszta klubba, ahol a varkocsba fogott szakállát látva lelkesen üdvözölték, és meghívták egy italra.

\section{Elmesélt történetek}

Diákoknál gyakoribbak, de ritkábban tanároktól is hallani olyan hosszabb-rövidebb beszámolókat, amelyeket általuk átélt vagy egy ismerősükkel megesett történetként ismerhetünk meg. Ilyen például Gyurinak [diák] a képzettség, a tudás és a státusz

19 Kétoldalt rövidre nyírt/leborotvált, közepén vékony, hosszanti sávban hosszúra hagyott haj. A punk stílus ismertetőjegye (Hebdige 1979). Eredetileg a háborúba induló észak-amerikai mohawk indiánok hajviseleteként vált ismertté (King 2009).

20 A butch és a femme az 1950-es évektől a (főleg munkásosztálybeli) leszbikus közösségekben (akár normatív elvárásként is) megjelenő, sztereotipikus férfias/nőies megjelenéssel és viselkedéssel járó szerepek. A butch/femme megjelenés és viselkedés, illetve ezek jelentése azóta (részben a feminista és queer politikai mozgalmak hatására) megváltozott. Amíg egyesek a heteroszexuális normák átvételét látják benne, addig mások a heteroszexuális férfiasság és nőiesség kritikáját vagy átalakítását, megint mások számára csupán esztétikai jelentősége van. (Hudson 2015; O’Brien 2009) A diákházi „butch” lányok jellemzően az elsődleges nemi jegyeket, illetve a csípő és a lábak formáját elrejtő bő ruházatot (kapucnis pulóvert, nadrágot), valamint jellegzetes, oldalt rövidre nyírt, a fejtetőn hosszabbra hagyott és oldalra fésült vagy elöl "kacsafarok" formában, esetleg mohawkra emlékeztető módon felállított hajat hordtak.

21 Itt elsősorban szimbolikus devianciáról van szó. Az anyagi okokra visszavezethető deviáns viselkedés és a szimbolikus deviancia közötti különbségtétel már Cohennél (1955) megjelenik. Anderson (2014) a szimbolikus deviancia fogalmát kiterjeszti azokra, akik önmagában (a fehér, középosztályi, heteroszexuális, férfi standardtól való) bármilyen különbözőségük, másságuk miatt deviáns vagy kívülálló státuszba kerülnek (pl. feketék, homoszexuálisok), amire válaszul az ellenállást és a "másság" ünneplését választják, pozitív identitáselemet kreálva belőle. A szimbolikus devianciát megkülönbözeti a deviáns cselekvésekkel (pl. drogkereskedelem) is társuló valódi devianciától.

22 Az igazgatói pozíció adminisztrációs elvárások miatt névlegesen létezik a Diákházban, és bár egy magasabb státuszú tanár tölti be, kiemelt döntési/irányítási jogkör nem jár vele. Ezeket a stáb együttesen gyakorolja. 
közötti kapcsolatot megkérdőjelező története egy modortalan, gyenge jellemú egyetemistáról.

Gyuri [diák]: „Múltkor állok a Mekiben, és áll a sorban egy közgázos csávó, és minden elözmény nélkül beszól az eladó csajnak, nem tudom, tán nem bírta a sorban állást. A csaj meg sírva fakadt, erre jön a fönök, hogy mi van. Félrehivják a srácot, elbeszélgetnek vele, mondja neki a fickó, hogy »úgy megverlek, hogy az anyád nem ismer rád«. Na, erre már a srác is sírt, hogy »csak vicceltem«. „Persze, mi is csak viccböl verünk meg, semmi komoly", tudod. Meglepödtem, hogy a közgázos ilyen köcsög, azt hittem, hogy azok ennél intelligensebb emberek."

Gábor [diák]: „Á, dehogy.”

$\mathrm{Az}$ a formalitásokat hangsúlyozó világról alkotott kép, amelyben nem a tényleges képességeket/tudást értékelik, illetve ahol a butaságot akár többre tartják, mint a tudást, a tanárok történeteiben is többször megjelenik. Egy nem stábtag, de a külsős tanároknál gyakrabban megjelenő tanártól, Andrástól hallottam talán a legérdekesebbet, amely a pedagógusok munkáját értékelő formális rendszer (és így az értékelők és az értékeltek) utolérhetetlen butaságáról szól.

András [tanár]: „Írtam a [pedagógus] feleségem helyett egy dolgozatot, amit valami országos alkalmassági vizsgán kellett leadni. Azt kérte, hogy annyira rosszat írjak, amennyire tudok. Írtam egy nagyon rosszat. A feleségem megnézte, és elsírta magát, hogy nem jó, mert összefüggö története van. Erre írtam egy scriptet, ami minden xedik mondatot kimásolt, és beszúrt pár sorral lejjebb, hogy legyen benne ismétlés. Valahonnan kiszedte az alanyt, máshonnan az állítmányt, random kiszedett vagy beírt vesszöket és hasonlók. A feleségem leadta, és ötöst kapott."

Ezek a „megtörtént” esetek példabeszédszerűek abban az értelemben, hogy a bennük szereplő karakterek és események megjelenítenek bizonyos jelenségeket, ideákat. A történetek előadói (vagy a hallgatóság) által pedig kimondatnak olyan értékítéletek, tanulságok, amelyek alkalmasak arra, hogy a diákházasokkal megismertessenek, illetve megerősítsenek bennük bizonyos közös koncepciókat. Gyuri [diák] és András [tanár] történeteinek tanulságát például valahogy úgy lehetne lefordítani, hogy a „státusz nem tesz senkit jó emberré”, vagy hogy „az okosság marginalizáló hatású a hülyék társadalmában”. Ezek a koncepciók segíthetnek abban, hogy a formális struktúrában státuszvesztést vagy a marginalizáció különböző formáit megélő diákházasok átkeretezhessék a pozíciójukat, más jelentést adjanak neki, és valamivel jobban érezhessék magukat. Ugyanakkor a formális státuszrendszer (struktúra) történetekben megjelenő kritikája, illetve a kritizálás aktusában való közös részvétel a diákházasok közötti communitas élményét is erősíti. 


\section{Beszélgetökörök}

A diákházi közösségi élet legfőbb színtere a tanári szoba, ahol szünetekben lépni nem lehet a diákoktól. Jellemzően itt szoktak kialakulni olyan néhány fős beszélgetőkörök, amelyek társalgását (ha számukra érdekes témáról folyik) a többi jelenlévő is intenzív figyelemmel követi, és néha hozzá is szól. Általában a tanárok és diákok közös részvételével zajló beszélgetések kapnak nagyobb figyelmet, illetve azok, amelyek valamilyen provokatív megnyilvánulással kezdődnek.

Ilyen volt Dóri [diák] esete, aki a tanáriban többek jelenlétében erősen negatív kritikát mondott egy Bálint [tanár] által készített szórólapról. Bálint elvörösödött, amire Dóri szinte örömmel jegyezte meg, hogy „látom az arcodon, hogy megsértődtél”. Anna [tanár] felvetette, hogy Dóri valamiért haragszik a tanárokra. Ezt Dóri először tagadta, majd elismerte. Az ebből kiinduló beszélgetés már az ő problémájáról szólt, arról, hogy elégedetlen az órabeosztása miatt, és igazságtalannak érzi egy írásbeli vizsgára kapott osztályzatát.

Dóri [diák]: „És én ezt [a helyes választ] megírtam, de a Renáta [tanár] nem fogadta el.” Anna [tanár]: „De miért nem mondtad még akkor a Renátának ezt?”

Dóri [diák]: (sértett hangon és arckifejezéssel) „Én nem fogom mondani.” Anna [tanár]: „De hát akkor ki képviselje ezt, ha te magad nem képviseled?”

Dóri [diák]: (továbbra is sértetten) „A Renáta ilyen feladatokat ad nekem, de nem értem őket, és most nincs óránk, csak ezek a feladatok. Hát hogyan csináljam meg? Nekem nincsenek szüleim, akik segitsenek. Másoknak segítenek a szülei. Még az intézetisek is kapnak segítséget. Én nem kapok semmit."

A beszélgetés néhány jelenlévő csatlakozásával folytatódott, immár Dóri sikeres vizsgáiról. Más diákok csendben figyelték az eseményt, vagy arcokat vágtak Dóri panaszkodására. Mindenesetre vele együtt tapasztalhatták meg azt a diákházi környezetet, amelyben (a hajléktalanszállón lakó) Dóri marginális helyzete nem kelt visszatetszést, hanem magától értetődően illeszkedik a diákházi sokszínúségbe. Láthatták, ahogy Anna a haragos támadások, illetve az áldozati szerep felvétele helyett saját érdekei aktívabb képviseletére buzdítja Dórit, és megtapasztalhatták, hogy a Diákházban a tanár-diák viszonyba belefér az ellenérzések nyílt kifejezése, és olykor még a sértegetés is.

Egy másik példa, amikor Igor [diák] összetalálkozott a tanári előtt Istvánnal, az igazgatóval, és minden előzmény nélkül feltételezte róla, hogy drogot fogyasztott.

Igor [diák]: (lapogatja István [tanár] hátát) „Mi a pálya? Betoltál egy vödör gombát?” István [tanár]: „Nem, csak metilalkohol.”

Igor [diák]: „Arcszesz?” [István ikonikus ismertetőjele a hosszúra növesztett szakálla]. István [tanár] és Attila [tanár]: (nevetnek) Attila [tanár]: „Vannak annál jobb aromájúak is.” 


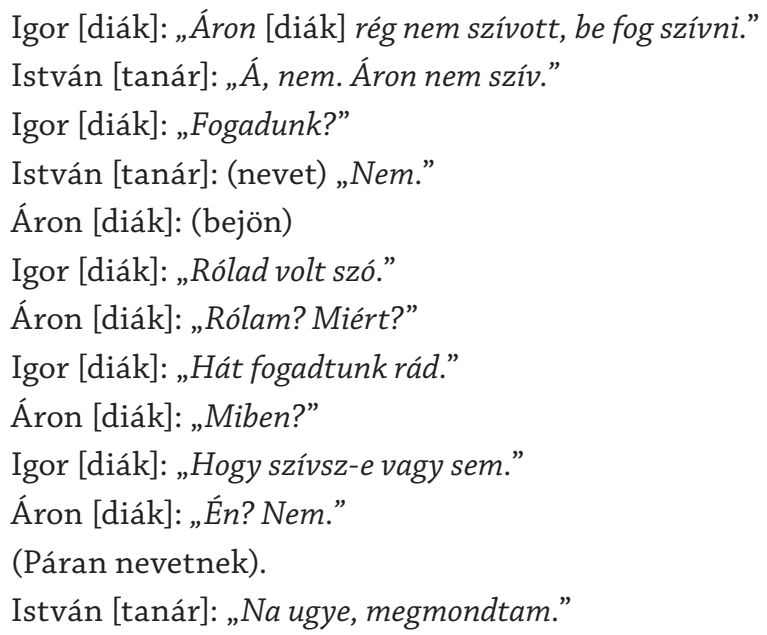

A Diákházban érvényes kevés formális szabály ${ }^{23}$ közül az egyik a drog- és alkoholfogyasztás tilalma, amelyet a tanárok igen szigorúan vesznek. Beszélni viszont lehet róla. Igor megnyilvánulásai annak kipuhatolására irányuló kísérletnek is tekinthetők, hogy mit bír el a tanár-diák viszony, meddig lehet elmenni a téma tárgyalásában, ugyanakkor több jellegzetes diákházi koncepció is tükröződik ebben az interakcióban.

Már az üdvözlés módjában (hátlapogatás) és a beszélgetés hangnemében (berúgós anekdotázások stílusa) megjelenik a communitas. Ugyanígy a beszélgetés tárgyában is megjelenik az a közösségi viszony, amelyben megoszthatók egymással az ilyen kényes tartalmak, de a drog témája a devianciát is megjeleníti. Továbbá fontos, hogy szinte az egész beszélgetés ironikus megjegyzésekből áll. Igor előhozza egy (a Diákházban amúgy is drogfogyasztó hírében álló) diáktársáról, hogy drogot fogyaszt. István úgy tesz, mintha nem hinné el, amire Igor úgy tesz, mintha elhinné, hogy István nem hiszi el, és bizonygatni kezdi neki. Később az érintett diák (ironikusan) tagadja, hogy használna drogot, amire István úgy tesz, mintha elhinné. Ez a (Geertz sűrű leírását példázó kacsintásokhoz és álkacsintásokhoz ${ }^{24}$ hasonló) sorozatos és kölcsönös ironizálás, a résztvevők közötti „összekacsintás” megjelenít egyfajta cinkosságot, amely (a jelenet nézőivel együtt) összekovácsolja őket egy közös, titkolt tudás birtokosaiként, és ilyen értelemben még a külvilággal, a konformmal szembeni (marginális) pozíciójukat is megerősíti.

\section{Performativ aktusok}

A fentieknél jóval látványosabbak a diákok alkalom szülte, egy-két fős „bemutatói”, amelyek rendszerint a tanáriban zajlanak. Témájuk gyakran valamilyen deviánsnak

23 A Diákházban a kutatásom ideje alatt mindössze három olyan formálisan rögzített szabály létezett, amely megsértése szankciót von maga után: a drog- és alkoholfogyasztás, valamint ezek árusításának tilalma, a fegyver vagy annak látszó tárgy behozatalának tilalma, amelyek megszegése esetén a diákot bármely tanár hazaküldheti, illetve a tanévenkénti legalább három vizsga letételének szükségessége, amely elmaradása esetén a tanulói jogviszony megszünik.

24 Geertz (2001) példájában a viselkedés által hordozott jelentések és az értelmezést lehetővé tévő körülmények sürü leírása szükséges, hogy egy tikkelést meg tudjunk különböztetni egy kacsintástól vagy egy kacsintást egy álkacsintástól. 
minősülő viselkedés vagy tulajdonság, amelyet a diákok jól láthatóan/hallhatóan, eltúlozva jelenítenek meg.

Egy alkalommal Detti [diák] tubákot szórt a tanári asztalára. A tubákot a kokainfogyasztás filmekből jól ismert módjához hasonlóan egy vonalzóval két sávba rendezte, majd egy szívószállal felszívta az orrába. Ezt olyan hosszasan és alaposan végezte, hogy a tanáriban jelen lévő tanár és öt diák már mind őt nézték. Bálint [tanár] a diákok kérdésére elmondta, hogy ez dohány, amelyet orrba szippantanak, és tüsszentenek tőle. Erre Máté [diák] (mintegy megbizonyosodva a dolog ártalmatlanságáról) kért Dettitől, majd követte a mintáját, de még alaposabb munkával „felaprítva" a már amúgy is porított dohányt. Bálint végül jó szándékúan elmagyarázta nekik, hogy a tubákot a kézfejről szokták beszippantani, és nem kell hozzá szívószál.

Rá pár napra Máté [diák] behozott legalább egy tucat, spanglihoz ${ }^{25}$ hasonlóra sodort cigarettát, amelyeket füstszűrővel is ellátott. A cigarettákat a drogterjesztőkhöz hasonlóan légmentesen záródó zacskóban tárolta, amelyet néha megmutatott diáktársainak, illetve kínálta is a cigarettákat. Végül egy diák elfogadott egy szálat, de később elfelejtkezett róla, és otthagyta a tanári asztalán.

Hagyományos iskolai környezetben valószínúleg mindkét eset botrányosnak minősülne, diákházi nézőpontból azonban inkább megmosolyogtató, ahogyan ezek a diákok látványosan, de igen esetlenül eljátsszák a drogfogyasztót/dílert. A kisgyerekek szerepjátékaihoz hasonlítható, amikor iskolai eszközökkel helyettesítik a fogyasztás kellékeit, vagy ahogy a „veszélyes életmód” eljátszása közben is megjelenik egyfajta biztonságra törekvés (füstszűrő a „spangliban”).

Hasonlóan színpadias jelenetek kötődtek a női homoszexualitás témájához. Három diáklány (Edina, Márti és Detti) gyakran intenzív öleléssel köszöntötte egymást, néha más diáklányokat is, és ezt olykor hangosan kommentálták is (pl.: „te voltál az első szerelmem"). Harsányan osztottak meg pikáns információkat, történeteket kapcsolataikról, a leszbikus közösségről, ahova bejáratosak voltak, és még sokféle módon prezentálták szexuális vonzódásuk irányát. Ez gyakran a tanáriban zajlott, ritkábban órákon, de mindig a diákházasok alkotta publikum előtt, és elég hangosan vagy látványosan ahhoz, hogy minden jelenlévő hallhassa, láthassa.

Ezeknek a megnyilvánulásoknak a lényege nem a bennük részt vevő lányok leszbikus identitásában keresendő. A Diákházban ennek (pláne sokadjára előadva) nincs információértéke, és megkockáztatom, hogy önmagában a szexuális/érzelmi vonzódás tényleges átéléséhez sem szükséges ekkora felhajtás. Ezek sokkal inkább olyan provokatív aktusok, amelyek hatása - legalábbis a hazai társadalmi környezetben - a homoszexualitás nyílt felvállalásával járó felforgató potenciálra épül. Valójában ezek is a „drogozós” előadásokhoz hasonló szerepjátékok, amelyek lényege a társadalmi renddel ellentétes, azt megkérdőjelező, deviáns magatartás vagy állásfoglalás eljátszása, a fennálló rendtől „távoli”, biztonságos körülmények között. Erre utal az is, hogy a

25 A marihuána vagy hasis fogyasztásának elterjedt módja. A hatóanyagot dohánnyal keverve, tölcsérszerűen szúkülő cigarettapapírba sodorják. 
normával való szembefordulásuk kifejezését néha már-már az extremitásig fokozták. Egyszer például Detti megjegyzése után, miszerint hányingert kapott egy csókolózó heteró pár látványától, Mártival nagy hévvel licitálni kezdtek egymásra, hogy ki utálja jobban, ha heteró párokat lát az utcán. (Egyébként a tanárok szerint Detti és Márti ilyen megnyilvánulásai a traumafeldolgozás egy formájának is tekinthetők, amelyhez Detti esetében az apjától elszenvedett szexuális bántalmazások, Mártinál pedig egy korai, sérüléseket okozó heteroszexuális viszony is hozzájárulhattak.)

A társadalmi marginalitás, hátrányos megkülönböztetés hasonló megjelenítésére is vannak példák. Anett [diák] élen járt az ilyen aktusok bemutatásában. Cigányként tudatosan foglalkozott saját társadalmi helyzetével, kirekesztettségével, aminek keretében például egy, a rasszizmus témáját körüljáró színházi előadásban is részt vett, és cigány iskolatársait is erre kapacitálta. Az ilyen irányú aktivitásába illeszkedtek azok az esetek, amikor a tanáriban cigányviccek mesélésére próbálta rábírni nem cigány diáktársait, vagy amikor messziről hallható, éles hangján nagy élvezettel (és egyébként igen szépen) énekelte, hogy „négy kopasz a téren egy cigányt ver éppen”. Utóbbi egy antifasiszta dal kezdő sora, amelyet a jelenlévők vagy felismertek, vagy ha nem, a folytatásból ${ }^{26}$ rájöhettek. Mégis, ez a felütés, ahogyan a cigányviccek gyüjtése is, kellően zavarba ejtő - vagy akár fájdalmasnak is mondható - ahhoz, hogy felhívja a jelenlévők figyelmét Anett problémájára. Anettnek ezek a produkciói nemcsak általánosságban irányították rá a figyelmet a társadalmi előítéletek, a kirekesztés és a marginalitás jelenségeire, hanem a jelenlévők itt „első kézből” kaphattak benyomásokat, az elszenvedő szemszögéből is rátekinthettek erre a jelenségre. A cigányviccek gyüjtése (mindenki feszengve tagadta, hogy akár egyet is ismerne) arra is utal, hogy valamilyen módon a diákházi diákok is érintettek a témában (és valóban, elvétve bár, de találkoztam rasszista kijelentésekkel, illetve éppen ebben az időszakban egy skinhead diák is járt a Diákházba). Ugyanakkor Anett ezekkel az előadásaival olyan védett helyként mutatta meg a Diákházat, ahol a „másság” tolerált, ahol nyugodtan felhozhatja a sérelmeit, és akár hangosan ki is énekelheti magából. (A diákházi toleráns légkör egyébként valamelyest hat az előítéletek lebontására. Az iskolai mindennapokban természetes, hogy a skinhead fiú az egyik cigány lánnyal közös programot szervez, illetve több diák is beszámolt róla, hogy jobban megismerve cigány társait felülírta a cigányságról alkotott korábbi általánosító, kirekesztő elképzeléseit).

\section{Összegzés helyett: a communitas diákházi funkciói}

A fentebbi néhány példán keresztül azt mutattam be, hogy a communitas élménye hogyan jön létre, és hogyan jelenítődik meg a diákházi mindennapokban. Ezek a

26 A Hétköznapi Csalódások punkzenekar Ostoba című számának részlete: „Négy kopasz a téren egy cigányt ver éppen / Ránézésre látszik: bátor neonácik / Négyen egy ellen, feddhetetlen jellem / Felsőbbrendú faj, csak egy a baj: hogy / Ostoba, ostoba, jaj de ostoba, ostoba állat / Ostoba, ostoba, jaj de ostoba, sötét bunkó. / Dicsekszik az egyik: én például eddig / tíz romát levertem, kettesével persze / A legidősebb elmúlt kilenc és fél éves, / De álltam a sarat a túlerőhöz képest. / Ostoba, ostoba, jaj de ostoba [...]" (Punksipka 2021) 
devianciát, drogot, homoszexualitást, hajléktalanságot, cigányságot, kirekesztettséget, a státuszrendszer megkérdőjelezését és egyebeket ábrázoló megnyilvánulások a diákok marginalitását és ellenállását, másképpen a struktúrából való kilépést, kikerülést, kiszorulást, illetve a struktúrával való szembefordulást (vagyis a communitas definitív elemét) is megjelenítik. Amíg a diákok korábbi iskoláiban ezek a jellemzők, problémák és megnyilvánulások (más okok mellett) az iskolából való kikerüléshez járultak hozzá, addig a másság értékét középpontba helyező Diákházban az intézménybe, illetve az intézményi színtéren zajló kommunikációba való beilleszkedésüket segítették. A lehetőség az ilyen témák kommunikálására, a hagyományos iskolai formalitások és szabályozás kerülése, valamint a közvetlen viszonyok egy olyan hely képzetét keltik a diákházasokban, amely kívül áll a struktúrán.

A diákházi communitas szerepe részben nagyon praktikus. Ahogyan már említettem, egyrészt segít a tanároknak kapcsolatba kerülni a diákokkal, de emellett felszabadulást is hoz a normatív társadalmi nyomás alól, amely segíti a diákokat, hogy erejüket a formalitásoknak való megfelelés helyett a tanulásra koncentrálhassák. Másrészt a Diákház, egyfajta szolgáltatásként, a szubkulturális csoport által nyújtott szociális előnyökhöz hasonlókat tesz elérhetővé az iskola tagjai számára. Rácz (1998) a rendszerváltás előtti időszak hazai szubkultúrái kapcsán írja le a szubkultúrába vezető út jellemző motívumait. Ilyen az intézményi közegből kikerülő fiataloknál az intézményi szerep-, státusz- és identitásrendszer érvénytelenné, elérhetetlenné válásával járó szociális vákuum érzése, a fojtogató kontroll intézményes rendszerekben megjelenő érzése, az iskolai értékekkel, normákkal vagy a kortárscsoportokkal konfliktusba kerülő, kudarcot valló fiatalok kirekesztettsége, illetve a nagyobb szocializációs zavarokat el nem szenvedő fiatalok önkéntes kivonulása. A szubkultúra közös háttértudást, saját világmeghatározást kialakító csoportként szocializáló szerepet tölt be a szociális űrben magukra maradó fiatalok számára. Biztonságot nyújt a társadalom leértékelésével szemben, ugyanakkor alkalmas a domináns kultúrával való szembenállás kifejezésére. Egyszerre teszi lehetővé/átélhetővé a deviációt és a (konvencionálistól lényegesen elütő csoporthoz való) konformitást. ${ }^{27}$

A szubkultúrával szemben a Diákház azonban egy strukturális intézmény. A szubkulturális/zenei együttlétekkor, illetve más közösségi alkalmakkor spontán létrejövő egzisztenciális communitastól Turner (2002) megkülönbözteti a normatív communitast, amikor egy csoport az előbbi élményét hosszabb ideig igyekszik fenntartani, amelyhez erőforrásokat kell mozgósítani és megszervezni, így a csoport tagjainak ellenőrzése is szükségessé válik. ${ }^{28}$ Utóbbi valójában már a struktúra része, mert a spontán communitas viszonyainak fenntartásáról, a fenntartás társadalmi feltételeinek megteremtéséről szól. Az általam leírt diákházi forma a normatív

27 Ez a szubkulturális múködésnek egy összevont, általánosító jellemzése, és a benne foglaltak nem egyformán érvényesek a Rácz (1998) által leírt csöves, punk, skinhead és underground szubkultúrákra. Ebben a formában leginkább az utóbbira jellemzők, amelynek egyébként több diákházi tanár is tagja volt.

28 Harmadik típusként Turner (2002) megjelöli még az ideológiai communitast, az egzisztenciális communitasra épülö utópisztikus társadalommodelleket. 
communitas példája. Az iskolai struktúra teszi fenntarthatóvá a communitas-élményt (tehát nem tényleges communitast), amely a diákok (és a tanárok) számára így nem csak a szubkulturalisták összejöveteleihez hasonló spontán helyzetekben élhető át, hanem az iskolai színtér keretein belül hosszabb ideig, visszatérő és kiszámítható módon. A communitas élménye pedig elfogadhatóvá teszi számukra az iskolai hierarchikus struktúrát. A communitas közvetlenebb viszonyai között a tanárok viselkedése akár nyílt kritika tárgyává is tehető, magasabb státuszuk megkérdőjelezhető, és a megkérdőjelezhetősége miatt legitimálhatóvá válik a struktúrával szemben alapvetően bizalmatlan diákok szemében. ${ }^{29}$

Itt meg kell jegyeznem, hogy ez az iskolai keret nem minden diák esetében hatékony, illetve a közösségben komoly feszültségeket is generál. Bár nem sokan, de minden évben vannak, akik csak a communitas élményében merülnek el, viszont nem használják ki a Diákház nyújtotta lehetőségeket a tanulásra és a vizsgázásra (a struktúrában való előrelépésre). Közülük többen szinte állandóan jelen vannak az iskolában, de az órákra ritkán ülnek be, és sok esetben végül a Diákházból is kihullanak. Az ilyen eseteket általában a tanárok és az érintett diák több sikertelen problémamegoldó tanácskozása és megegyezése előzi meg. Ők gyakran a tanárok által „éretlenebbnek" ítélt diákok, akiket az esetek egy részében évekkel később - ha már alkalmasnak látják őket a diákházi munkára - újra felvesznek. De a communitas-élmény és az elfogadó légkör az egyébként motivált diákok egy részénél is kontraproduktív lehet, illetve kialakíthat egyfajta függőséget. Ahogyan Zita [diák] mondta: „Már nem is akarok érettségizni, mert akkor el kéne menni innen. Elkezdtem ide járni, és itt azt érzem, hogy végre boldog vagyok. Nem akarok elmenni." Vannak ugyanakkor olyanok is, akik a communitas-élménybe és a vele járó közvetlen viszonyokba nem tudják/akarják beleengedni magukat, és igényük volna egy erôsebben strukturált rendszerre. A Diákház személyre szabott pedagógiája képes bizonyos mértékig reagálni erre (magázódnak a diákkal, ha arra van igénye, vagy szigorúbb elvárásokat, értékelést kap, ha ez motiválja a felkészülésben), de találkoztam olyan diákkal is, aki inkább más, hagyományosabb iskolába iratkozott át.

Ahogyan a vizsgák kapcsán már utaltam rá, a communitas és a struktúra párhuzamos jelenlétéből fakadó ellentmondásos helyzetek (pl. a communitas viszonyait érvényesíteni igyekvő diáknak adott tanári utasítások) feszültségekhez vezethetnek, amelyeket nem mindenki tud egyformán kezelni. Pl. Natinak új tanárként nem volt könnyű a diákházi viszonyokba beleszoknia, és a diákok provokatív megnyilvánulásait sokszor próbálta autoriter módon (szankciókkal való fenyegetéssel) kezelni - többnyire sikertelenül. A diákok között pedig vannak, akik a feszültséget inkább csak maguk között ventilálják annak ellenére, hogy léteznek erre alkalmas formális és nem formális módok. Ilyen például a diákok érdekérvényesítő fóruma, a „diák-

29 Itt nem a hierarchikus viszonyok átmeneti elviseléséről van szó, hanem a diákok bizonyos szintű azonosulásáról az iskolai koncepciókkal (beleértve olyanokat is, mint az önállóság, a felelösségvállalás, a tudás megszerzése). Részletesebben ld. Szentesi 2019b. 
stáb" vagy az egyéni mentoráló beszélgetések, valamint a tanárok magasabb státuszát megkérdőjelező megnyilvánulások és a (helyenként igen vaskos) tréfálkozások hol a diákok, hol a tanárok részéről. ${ }^{30}$ Ugyanakkor éppen ez, a diákházi diskurzust belülről feszítő és hajtó ellentmondás, a struktúra és a communitas élménye közötti állandó egyensúlyozás teszi fenntarthatóvá az iskolai múködést hagyományos iskolai formalitások, gyakorlatok és hatalmi viszonyok nélkül.

A Diákház célja, hogy segítsen felkészülni az érettségire olyan diákoknak, akik - bár képesek volnának rá - „kívülállóságuk” (devianciáik, hátrányos helyzetük, egyéb hátráltató tényezőik) miatt akadályoztatottak ebben. Erre nyújt egyfajta megoldást a szubkulturális koncepciók és a communitas beemelése az iskolai múködésbe, amellyel a Diákház a „kívülállóságot” módszertani elemként illeszti be az oktatási rendszerbe, és ezáltal az iskolából korábban kimaradó diákok számára a struktúrán való kívülállás élményének átélése válhat a strukturális pozícióemelkedéshez (érettségi) vezető úttá.

\begin{abstract}
The study examines the internal discourse of an alternative grammar school (the „Diákház”) in Budapest based on the results of an ethnographic research. The teachers of the Diákház deal with socioculturally diverse early school leavers who mostly feel some rejection to adults, teachers and schools. Besides the pedagogical methods, different from traditional ones, the subcultural concepts of the discourse help their work: the otherness, deviance, resistance against the mainstream, marginality and the communitas, the experience of a community without status differences. This paper demonstrates how the communitas, maintained within the educational framework, appears and is reinforced on the Diákház communication scene, and how the feeling to be out of the structure endorses students' progress in the structure.
\end{abstract}

Keywords: communitas, subculture, alternative education, school dropout

\title{
Irodalom
}

Anderson, L. (2006): Analytic autoethnography. Journal of Contemporary Ethnography, 35(4): 373-395. https://doi.org/10.1177/0891241605280449

Anderson, T. L. (2014): Connections. Marginality, identity and music scenes. In uő (ed.): Understanding deviance. Connecting classical and contemporary perspectives. London: Routledge, 507-516. https://doi.org/10.4324/9781315879635

Anderson-Levitt, K. M. (2012): Anthropologies and ethnographies of education worldwide. In uő (ed.): Anthropologies of education. A global guide to ethnographic studies of learning and schooling. New York: Berghahn Books, 1-28.

Bennett, A. (2003): The use of 'insider' knowledge in ethnographic research on contemporary youth music scenes. In Bennett, A. - Cieslik, M. - Miles, S. (eds.): Researching youth. New York: Palgrave MacMillan, 186-199. https://doi. org/10.1057/9780230522466_12

30 Ilyen esetek leírását és elemzését Id. Szentesi 2013a. 
Bourdieu, P. (1999): Gazdasági tőke, kulturális tőke, társadalmi tőke. In Angelusz R. (szerk.): A társadalmi rétegződés komponensei. Budapest: Új Mandátum, 156-177.

Brewer, J. D. (2005): Ethnography. Buckingham: Open University Press.

Clifford, J. - Marcus, G. E. (1986) (eds.): Writing culture. The poetics and politics of ethnography. Berkeley: University of California Press.

Cohen, A. K. (1955): Delinquent boys. The culture of the gang. New York: Free Press.

Csongor A. (1991): Szegregáció az általános iskolában. Cigány osztályok Magyarországon. Budapest: Oktatáskutató Intézet.

Delamont, S. (2012): The parochial paradox. Anthropology of education in the anglophone world. In Anderson-Levitt, K. M. (ed.): Anthropologies of education. A global guide to ethnographic studies of learning and schooling. New York: Berghahn Books, 49-69.

Ensminger, D. (2013): Slamdance in the no time zone. Punk as repertoire for liminality. Liminalities. A journal of performance studies, 9(3). http://liminalities. net/9-3/slamdance.pdf (utolsó letöltés: 2021. 01. 30.)

Erikson, E. H. (1950): Childhood and society. New York: Norton. https://doi. org/10.1126/science.113.2931.253

Erőss, G. (2012): Central Europe (Bulgaria, the Czech Republic, Hungary, Poland, Romania, Slovakia). In Anderson-Levitt, K. M. (ed.): Anthropologies of education. A global guide to ethnographic studies of learning and schooling. New York: Berghahn Books, 167-191.

Feischmidt M. - Nyíri P. (szerk.) (2006): Nem kívánt gyerekek? Külföldi gyerekek magyar iskolákban. Budapest: MTA Kisebbségkutató Intézet.

Geertz, C. (2001): Sưrű leírás. Út a kultúra értelmező elméletéhez. In uő: Az értelmezés hatalma. Antropológiai írások. Második, javított kiadás. Budapest: Osiris, 194-226.

Gelder, K. (2005): The field of subcultural studies. In uő. (ed.): The subcultures reader. 2. kiadás. London: Routledge, 1-15.

van Gennep, A. (2007): Átmeneti rítusok. Az ajtóhoz és a küszöbhöz, a vendégszeretethez, az örökbefogadáshoz, a terhességhez és a gyermekágyhoz, a születéshez, a gyermekkorhoz, a serdülókorhoz, a beavatáshoz, a felszenteléshez, a koronázáshoz, az eljegyzéshez, a házassághoz, a temetéshez, az évszakokhoz és más egyébhez kapcsolódó rítusok módszeres elemzése. Budapest - Pécs: MTA Néprajzi Kutatóintézete - PTE Néprajz - Kulturális Antropológia Tanszék - L’Harmattan.

Gyenge E. (2014): Krízisek gyermek- és serdülőkorban. In Vörös V. - Osváth P. Árkovits A. - Csürke J. (szerk.): Mindennapi kríziseink. A lélektani krízis és a krízisintervenció kézikönyve. 2. kiadás. Budapest: Oriold, 171-185.

Haenfler, R. (2013): Subcultures. The basics. London: Routledge. https://doi. org/10.4324/9781315888514

Hajduska M. (2015): Krízislélektan. 3. bővített kiadás. Budapest: ELTE Eötvös. 
Hall, S. (1996): Introduction: Who needs, identity'? In Hall, S. - du Gay, P. (eds.): Questions of cultural identity. London: Sage, 1-17. https://doi.org/10.4135/9781446221907.n1 Hall, S. - Jefferson, T. (eds.) (1976): Resistance through rituals. Youth subcultures in post-war Britain. London: Hutchinson. https://doi.org/10.4324/9780203224946

Haslop, C. - Hill, H. - Schmidt, R. A. (1998): The gay lifestyle. Spaces for a subculture of consumption. Marketing intelligence \& planning, 16(5): 318-326. https://doi. org/10.1108/02634509810229937

Hayano, D. M. (1979): Autoethnography. Paradigms, problems and prospects. Human Organization, 38(1): 99-104. https://doi.org/10.17730/humo.38.1.u761n5601t4g318v

Hebdige, D. (1979): Subculture. The meaning of style. London: Routledge. https://doi. org/10.4324/9780203139943

Hodkinson, P. (2005): Insider research in the study of youth cultures. Journal of youth studies, 8(2): 131-149. https://doi.org/10.1080/13676260500149238

Holmes, T. H. - Rahe, R. H. (1967): The social readjustment rating scale. Journal of psychosomatic research, 2: 213-218. https://doi.org/10.1016/0022-3999(67)90010-4

Horányi Ö. (szerk.) (2007): A kommunikáció mint participáció. Budapest: AKTITypotex, 246-264.

Hudson, A. M. (2015): Nail polish and polos. The workplace experiences of out femme and butch lesbians. Szakdolgozat. San Marcos: Texas State University.

Hutson, S. R. (2000): The rave. Spiritual healing in modern western subcultures. Anthropological quarterly, 73(1): 35-49.

King, D. C. (2009): The Mohawk. New York: Marshall Cavendish.

Linehan, M. M. (2010): A borderline személyiségzavar kognitív viselkedésterápiája. Budapest: Medicina.

Marcus, G. E. - Fischer, M. M. J. (1999): Anthropology as cultural critique. An experimental moment in the human sciences. 2. kiadás. Chicago: The University of Chicago Press.

Mészáros Gy. (2014): Szubkultúrák és iskolai nevelés. Narratív, kritikai pedagógiai etnográfia. Veszprém: Iskolakultúra.

Neumann E. - Zolnay J. (2008): Esélyegyenlőség, szegregáció és oktatáspolitikai stratégiák Kaposváron, Pécsen és Mohácson. Budapest: EÖKIK.

O’Brien, J. (ed.) (2009): Encyclopedia of gender and society. Thousand Oaks: Sage. https://doi.org/10.4135/9781412964517

Punksipka (2021): http://punksipka.mlap.hu/html/17754814/render (utolsó letöltés: 2021. 01. 30.)

Rácz J. (1998): A ‘80-as évek ifjúsági szubkultúrái Magyarországon. In uő (szerk.): Ifjúsági (szub)kultúrák, intézmények, devianciák. Válogatott tanulmányok. Budapest: Scientia Humana, 51-69.

Riemer, J. W. (1977): Varieties of opportunistic research. Urban life, 5(4): 467-477. https://doi.org/10.1177/089124167700500405 
Rill, B. (2006): Rave, communitas, and embodied idealism. Music therapy today, 7(3): 648-661.

Rohrer, I. (2014): Cohesion and dissolution. Friendship in the globalized punk and hardcore scene of Buenos Aires. Wiesbaden: Springer. https://doi.org/10.1007/978-3-658-04360-5

Shannon, C. E. - Weaver, W. (1986): A kommunikáció matematikai elmélete. Az információelmélet születése és távlatai. Budapest: Országos Műszaki Információs Központ és Könyvtár, 43-152.

Sylvan, R. (2002): Traces of the spirit. The religious dimensions of popular music. New York: New York University Press.

Szentesi B. (2013a): A (szub)kulturális kategorizáció mint pedagógiai eszköz. Egy alternatív középiskola belső diskurzusai kulturális és kommunikációs megközelítésben. In Szász A. - Kirzsa F. (szerk.): Kultúrakutatás és narrativa. Tanulmánykötet A. Gergely András tiszteletére 60. születésnapja alkalmából. Budapest: MAKAT - L’Harmattan, 296-310.

Szentesi B. (2013b): Konfliktusok és alkuk. Cigány gyerekek és magyar nevelők interkulturális diskurzusa egy oktatóprogram foglalkozásain. In Szuhay P. (szerk.): Távolodó világaink. A cigány-magyar együttélés változatai. Budapest: Magyar Néprajzi Társaság, 231-246.

Szentesi B. (2018): A belső pozíció haszna. A saját közösség kutatásának tapasztalatai. Kultúra és közösség, 9(4): 89-101. htttp://epa.niif.hu/02900/02936/00039/ pdf/EPA02936_kultura_es_kozosseg_2018_04_089-102.pdf (utolsó letöltés: 2021. 01. 30.)

Szentei B. (2019a): Másság és alkudozás. Az érvénytelenség problémájának megoldása egy alternatív gimnáziumban. Jel-kép, 40(1): 1-15. https://doi.org/10.20520/ JEL-KEP.2019.1.1

Szentesi B. (2019b): Másság, felelősségvállalás és tudás. A szubkulturális és intézményi értelmezések összefonódásának haszna egy alternatív gimnázium belső diskurzusában. Socio.hu, 9(3): 28-50. https://doi.org/10.18030/socio. hu.2019.3.28

Szentesi B. (2020): Struktúra és communitas. Szubkulturális problémamegoldó tudás egy alternatív gimnáziumban. Metszetek, 9(1): 153-174. https://doi. org/10.18392/metsz/2020/1/9

Tetnowski, J. A. - Damico, J. S. (2014): Auto-ethnography. In Forsyth, C. - Copes, H. (eds.): Encyclopedia of Social Deviance. London: SAGE, 48-50. https://doi. org/10.4135/9781483340470

Thornton, S. (1995): Club cultures. Music, media and subcultural capital. Cambridge: Polity.

Turner, V. (1957): Schism and continuity in an African society. A study of Ndembu village life. Manchester: Manchester University Press.

Turner, V. (1967): The forest of symbols. Aspects of Ndembu ritual. Ithaca: Cornell University Press. 
Turner, V. (2002): A rituális folyamat. Struktúra és antistruktúra. A Rochesteri Egyetemen (Rochester, NewYork) 1966-ban tartott Lewis Henry Morgan-előadások. Budapest: Osiris.

Viega, M. (2013): „Loving me and my butterfly wings.” A study of hip-hop songs written by adolescents in music therapy. Doktori disszertáció. Temple University, ProQuest Dissertations Publishing.

Watzlawick, P. - Beavin, J. H. - Jackson, D. D. (2009): Az emberi érintkezés. Formák, zavarok, paradoxonok. Budapest: Animula.

Willis, P. (2000): A skacok. Iskolai ellenkultúra és munkáskultúra. Budapest: Új Mandátum Könyvkiadó - Max Weber Alapítvány.

Yang, M. C. (1972): How a chinese village was written. In Kimball, S. T. - Watson, J. B. (eds.): Crossing cultural boundaries. The anthropological experience. San Francisco: Chandler, 63-73.

Zinn, M. B. (1979): Field research in minority communities. Ethical, methodological and political observations by an insider. Social problems, 27(2), 209-219. 